\title{
RASADNIČKA PROIZVODNJA ŠUMSKIH VOĆKARICA U RASADNICIMA HRVATSKIH ŠUMA D.0.0.
}

\author{
NURSERY PRODUCTION OF FOREST FRUIT TREES \\ IN NURSERIES OF CROATIAN FORESTS D.0.0.
}

\author{
Damir DRVODELIĆ ${ }^{1}$ Milan ORŠANIĆ ${ }^{1}$, Mirjana GRAHOVAC-TREMSKI²
}

\section{SAŽETAK}

U članku se definira pojam šumskih voćkarica ili šumskoga voća koji je godinama prisutan u hrvatskom šumarstvu i navedeni pojam se uspoređuje s ostalim pojmovima koji nisu istoznačnice, a odnose se na šumsko drveće, grmlje i prizemno rašće jestivih i ljekovitih plodova, samonikle voćke i domesticirane voćke. Za svaki pojam navode se tipični predstavnici vrsta. Prikazana je proizvodnja po vrstama drveća u rasadnicima Hrvatskih šuma d.o.o. u 2019./2020. godini prema upravama šuma podružnicama (UŠP), organizacijskim jedinicama i rasadnicima. Što se tiče proizvodnje šumskih voćkarica, drveća jestivih i ljekovitih plodova, samoniklog voća i domesticiranih voćki ista je prisutna u samo tri rasadnika Hrvatskih šuma d.o.o. (Zelendvor, Oštarije i Lukavec). U navedena tri rasadnika ukupno se proizvodi (2019./2020.) svega četiri vrste iz navedene četiri kategorije: oskoruša, divlja trešnja, pitomi kesten i crni orah. Sve četiri vrste se proizvode u rasadniku Zelendvor, dok se u rasadniku Oštarije proizvode šumske sadnice oskoruše i divlje trešnje, a u rasadniku Lukavec samo šumske sadnice divlje trešnje. Prikazana je proizvodnja i isporuka sadnog materijala navedenih vrsta iz rasadnika Hrvatskih šuma d.o.o. za razdoblje od 2012. do 2017. godine. Na zalihama ili u proizvodnji, u svim rasadnicima Hrvatskih šuma d.o.o. za razdoblje od 2012. do 2018. godine najviše je bilo sadnica crnog oraha u iznosu od 183670 komada, slijede sadnice divlje trešnje s 132 069 komada, pitomog kestena s 53010 komada i divlje kruške s 4882 komada. Najviše isporučenih sadnica, sukladno proizvodnji, bilo je kod crnog oraha i to u iznosu od 191435 komada, slijede sadnice divlje trešnje s 71954 komada, pitomog kestena s 28515 komada i divlje kruške s 2860 komada. U promatranom istraživanom razdoblju (2012.-2018.) u svim rasadnicima Hrvatskih šuma d.o.o. proizvodilo se samo 4 vrste iz navedenih kategorija, s ukupnom zalihom ili proizvodnjom od 373631 komada šumskih sadnica i isporukom od 294764 komada. Ukupno gledano za sve četiri vrste vidi se da je 78867 komada sadnica više uzgojeno nego što je isporučeno. Zbog mogućnosti ekološkog uzgoja, dobre prilagodljivosti vrsta na globalne klimatske promjene, davanja državnih poticaja i ne previše zahtjevne njege, u bliskoj budućnosti bit će sve naglašeniji uzgoj vrsta za pridobivanje sekundarnih ili ne drvnih šumskih proizvoda u plantažama. Zbog promjene klimatskih uvjeta i sinergizma brojnih nepovoljnih biotskih i abiotskih čimbenika, mnoge autohtone vrste su danas ugrožene i postepeno se ili naglo suše i propadaju. Nekim će vrstama šumskih voćkarica, šumskog drveća, grmlja i prizemnog rašća jestivih i ljekovitih plodova, samoniklih voćki i domesticiranih voćki pogodovati promjena klime, što će dovesti do širenja njihovog prirodnog areala, uz povećanje potencijalnih površina pogodnih za umjetni uzgoj.

KLJUČNE RIJEČI: rasadnička proizvodnja, crni orah, divlja trešnja, divlja kruška, oskoruša

\footnotetext{
Doc.dr. sc. Damir Drvodelić, Prof. dr.sc. Milan Oršanić, Šumarski fakultet Sveučilišta u Zagrebu, HR-10 000 Zagreb, Svetošimunska 25

2 Mirjana Grahovac-Tremski, dipl. ing. šum., Hrvatske šume d.o.o., UŠP Koprivnica R.J. Rasadničarstvo Koprivnica, HR-48 000 Koprivnica, Ulica Močile 12 korespodencija: doc. dr. sc. Damir Drvodelić, ddrvodelic@inet.hr
} 


\section{UVOD}

\section{INTRODUCTION}

Drveće i grmlje jestivih plodova ima višestruku važnost u šumskim ekosustavima. Služi kao hrana brojnim životinjskim vrstama koje obitavaju u šumi. Ove vrste su izvanredno važne za stabilnost šuma jer su:

- sastavni dio genetskog bogatstva naših šuma,

- nezamjenjiva karika u hranidbenom lancu za niz vrsta od mikroorganizama, kukaca, ptica, glodavaca i velikih biljojeda do velikih grabežljivaca,

- činitelj zdravstvene otpornosti šumskih sastojina,

- s ostalim vrstama drveća i grmlja stanište velikom broju drugih vrsta i

- mikrostanište različitim vrstama koje se na njima razvijaju (Šatalić i Štambuk 1997).

Šumsko drveće i grmlje, a posebno šumsko voće služi kao hrana mnogim životinjskim vrstama koje obitavaju unutar šume. Prema Andrašiću (1980), lisica, osim mesa, rado jede šumsko voće, kao i smeđi medvjed koji se uglavnom hrani biljnom hranom.

U šumske voćkarice ili šumsko voće pripadaju sporedne vrste drveća koje doprinose biološkoj raznolikosti sastojina, služe kao potpora glavnim vrstama drveća i poboljšavaju kvalitetu tla. Sporedne vrste drveća u šumama rastu pojedinačno, u manjim grupama ili skupinama i nikada u pravilu ne tvore čiste šumske sastojine. Zadatak sporednih vrsta drveća u mješovitoj sastojini je da pomažu rast i razvoj glavne vrste drveća, da pomažu prirodno čišćenje debla glavne veste drveća od grana, da ih zaštite od upale kore, mrazopuca, da stimuliraju brži rast glavne vrste drveća u visinu te da pomažu formiranju punodrvnoga debla. Sporedne vrste povoljno utječu na šumsko tlo obilnim količinama listinca, osiguravaju gušći sklop krošanja i na taj način zaštićuju tlo od neposrednoga utjecaja atmosferilija. U slučaju mješovite sastojine, šumskouzgojni postupci se obavljaju na način da pomažu glavnu ili glavne vrste drveća. U sastojini hrasta lužnjaka i običnoga graba, glavna vrsta drveća je hrast lužnjak, a sporedna obični grab ili neka šumska voćkarica kao što je divlja jabuka ili divlja kruška.

Oskoruša i brekinja imaju u Hrvatskoj veću ekološku nego gospodarsku vrijednost i zanemarene su usprkos vrlo cijenjenog drva. Danas se uzgajaju samo radi dobivanja plodova, a još prije šezdesetak godina njihovo drvo korišteno je za izradu različitih proizvoda i kao ogrjev (Matić i Vukelić 2001). Uz sve to, pojedine voćkarice imaju izuzetno kvalitetno drvo koje postiže visoku cijenu i u novije doba postoji sve veća potražnja za njim. Na primjer, zbog male i ograničene količine drva oskoruše na europskom tržištu cijena $1 \mathrm{~m}^{3}$ doseže i do 6000 eura (Drvodelić i sur. 2015).

Šumske voćkarice su vrste koje se često sade kao zaštitni šumski pojas (poljozaštitni, snjegozaštitini, vodozaštitini i antierozijski). Kapper (1952), piše o pogodnost mukinje za vjetrobrane pojase, kao pomoćnu vrstu u plantažama crnogorice i bjelogorice, za pošumljavanje područja černozema i za podstojnu etažu u sastojinama bora i hrasta na svježim i vlažnim tlima. Iako u našim prirodnim šumskim ekosustavima i raznim oblicima degradiranih šuma pridolazi mnogo drvenastih vrsta koje možemo svrstati u šumske voćkarice (šumsko voće), drveće, grmlje i prizemno rašće jestivih ili ljekovitih plodova, samonikle voćke i domesticirane voćke, tijekom povijesti nije se pridavala veća pozornost kako njihovom očuvanju i njezi u prirodi tako niti u rasadničkoj proizvodnji. Malo je pisanih radova o rasadničkoj proizvodnji šumskih voćkarica. Nitko nije jasno i temeljito definirao pojmove kao što su: šumske voćkarice ili šumsko voće, šumsko drveće, grmlje i prizemno rašće jestivih i ljekovitih plodova, samoniklo voće i domesticirane voćke i to donosi mnoge praktične probleme kako u šumarskoj i agronomskoj znanosti, tako i praktičnom razmnožavanju i uzgoju. Uz sve to nije razjašnjena podjela šumskih voćkarica i prikazan njihov popis kao dio zavičajnih vrsta Republike Hrvatske.

U Hrvatskoj enciklopediji (Leksikografski zavod Miroslav Krleža) navodi se definicija voća kao plodovi kulturnih ili samoniklih voćaka, koji se upotrebljavaju u prehrani u svježem ili suhom stanju i u obliku prerađevina (kompoti, džemovi, marmelade, slatko, sokovi i dr.). Prema pomološkoj klasifikaciji razlikuju se: jezgričavo voće, koštičavo voće, lupinasto voće, jagodasto voće, suptropsko ili južno, tropsko voće (banana, mango, avokado, anona, ananas, datulja). Voće ima veliku hranjivu i zaštitnu (dijetoprofilaktičnu i dijetoterapeutsku) vrijednost. Osnovni su sastojci voća: voda, šećeri, škrob, pektini, tanini, ulja, bjelančevine, celuloza, hemiceluloza, lignin, organske kiseline, mineralne tvari, vitamini, fermenti i mirisne tvari (aroma). Od šećera najviše ima glukoze, fruktoze i saharoze, a od organskih kiselina jabučne i limunske (https://www.enciklopedija.hr/ Natuknica.aspx? ID=65101).

Podjelu voća možemo načiniti prema više kriterija. Ako kao kriterij upotrijebimo godišnje doba u tom slučaju razlikujemo: proljetno, ljetno i jesensko voće. Tako podjela voća može biti na jabučasto, koštuničavo, jezgrasto, bobičasto, jagodasto i južno voće.

Najjednostavnija definicija voća glasila bi kako su to višegodišnje biljke čije plodove možemo jesti svježe. Prema vlastitim istraživanjima u navedenoj definiciji mnogi traže izuzetke i sigurno je kako nije do kraja razjašnjena. Tako je is podjelom voćaka, koja je još do danas predmet rasprava kako unutar znanosti tako i u praksi. Zbog preglednosti i lakšeg proučavanja stvoreno je više pomoloških klasifikacija, a kao najprikladnija se pokazala podjela voćaka prema osnovnim obilježjima i građi plodova prema kojoj razlikujemo: jezgričave voćne vrste (Pomoideae) (jabuka, kruška, 
dunja, mušmula i dr.), koštičave voćne vrste (Prunoideae) (šljiva, breskva, marelica, trešnja, višnja i dr.), lupinaste voćne vrste (lijeska, orah, kesten, badem i dr.) i jagodaste voćne vrste (jagoda, malina, kupina, borovnica, brusnica, ribiz, ogrozd, stolno grožđe i dr.). Posebne skupine voćaka čine: citrusi odnosno agrumi, južno, suptropsko voće i egzotično voće (http://pinova.hr/hr_HR/baza-znanja/vocarstvo/vocne-vrste).

Plodovi voća mogu biti klimakterijski i neklimakterijski. Klimakterijski plodovi odlikuju se maksimumom respiracije neposredno prije nastupa senescence (jabuka, kruška, dunja, oskoruša, mušmula, banana, kivika i avokado). Etilen ima jaki učinak na dozrijevanje plodova koji mogu dospjeti odvojeni od stabla. Kod neklimakterijskih plodova nema jasno izraženog maksimuma respiracije (trešnja, višnja, smokva, grožđe, ananas, jagoda, malina, kupina,naranča, limun, mandarina i grejpfruit). Plodovi navedenih vrsta ne mogu dospjeti odvojeni od stabla. Postoji i pojam plodova s potisnutim klimakterijem, a odnosi se na neke sorte šljiva kod kojih je koncentracija endogenog etilena i do 500 puta manja od uobičajene. S gledišta sakupljanja neklimakterijskih plodova za potrebe rasadničke proizvodnje, važno je znati da sjeme u njima ne dozrijeva kad se plod otkine sa stabla. Tako su mnogi propusti učinjeni npr. s plodovima divlje trešnje koji su ubrani u nezrelom stanju i vitalitet takvog sjemena iznosio je nula \%.

S obzirom na povoljne stanišne prilike (klima i tlo), u Hrvatskoj prema navedenoj podjeli mogu uspijevati sve navedene skupine voćaka, što nas čini rijetkom državom u Europi. Sve te pogodnosti trebali bi više vrednovati, znanstveno proučavati, o njima pisati i u konačnici ih pretvoriti u konkretan uzgoj u šumskim plantažama ili voćnjacima.

Šumske voćkarice ili šumsko voće do sada nitko nije podijelio u skupine prema osnovnim obilježjima i građi plodova iz razloga što se neke vrste mogu svrstati u pojedinu skupinu ali ne sve. U šumarstvu treba razlikovati sljedeće pojmove: šumske voćkarice ili šumsko voće, šumsko drveće, grmlje i prizemno rašće jestivih i ljekovitih plodova, samonikle voćke i domesticirane voćke. Šumske voćkarice su asocijalne vrste koje rijetko tvore biljne zajednice ili šumske fitocenoze, a u sastojinama rastu kao pojedinačna stabla ili u većim ili manjim skupinama i grupama. Pojedine vrste šumskog voća poput divlje jabuke najbolju ekološku nišu imaju na rubovima šuma gdje je fruktifikacija obilna, dok druge vrste poput oskoruše često rastu kao soliterna stabla u starim voćnjacima oko kuća, uz putove, vinograde, na livadama, na kršu ili rjeđe u šumskim sastojinama niskog i srednjeg uzgojnog oblika, a vrlo rijetko u sjemenjačama. Šumske voćkarice doprinose biološkoj raznolikosti šumskih sastojina, njihovim svježim plodovima se hrani čovjek i životinje (divljač, ptice, stoka) i mikroorganizmi u tlu. Upravo su životinje glavni prenositelji sjemena šumskog voća, a mikoorga- nizmi razgradnjom plodova i otpale organske tvari (lišće, izbojci, grane, kora,...) povećavaju mikrobiološku aktivnost tla i doprinose procesu kruženja makro i mikro hranjiva u prirodi. Iz toga razloga može se reći kao je šumsko voće izuzetno važno, posebno u čistim sastojinama gdje povećavaju stabilnost i produktivnost glavne socijalne vrste drveća.

S gledišta sabiranja i ekstrakcije (vađenja) sjemena, možemo sjeme svrstati u tri grupe: pravo sjeme, suhi plodovi i mesnati plodovi (Regent 1980). S obzirom na navedenu podjelu, šumske voćkarice pripadaju u grupu mesnatih plodova (Sorbus domestica L., Malus sylvestris Mill., Cornus mas L., Ziziphus jujuba Mill., Rubus idaeus L., Fragaria vesca L., itd.).

Kod šumskih voćkarica ili voća važno je napomenuti da ih čovjek konzumira u svježem ili neprerađenom stanju i u vrijeme njihove potpune zriobe koja ovisi o vrsti i podneblju. Većina vrsta je zoohorno. Sve vrste šumskih voćkarica mogu se preraditi u mnoštvo raznih i skupocjenih proizvoda. Važno je naglasiti kod šumskih voćkarica ili voća da rastu na šumskom i degradiranom šumskom tlu. Tako ih susrećemo od prirodnih šumskih zajednica do raznih oblika degradacijskih šuma eumediterana (makija, rjeđi i gušći garig i kamenjara) i submediterana (šikara, šibljak i kamanjera). Prema fitocenološkoj klasifikaciji, šumsko voće raste u sloju drveća (Sorbus domestica L.), grmlja (Cornus mas L.) i prizemnog rašća (Fragaria vesca L.). Okus šumskih voćkarica podsjeća često na drage uspomene iz djetinjstva, budući ih danas ljudi sve manje konzumiraju zbog sve manjeg učešća stabala u prirodi i nemogućnosti kupovine na tržnicama ili trgovinama s voćem.

Pretpostavka je kako od prirode u Hrvatskoj raste između 30 i 40 vrsta šumskog voća ili šumskih voćkarica. Točan popis vrsta do sada nije sastavljen i to treba što prije napraviti, a u istraživanje treba uključiti šumare i agronome. Navedenom problematikom do sada se nije nitko bavio.

Drugi pojam odnosi se na šumsko drveće, grmlje i drvenasto prizemno rašće jestivih i ljekovitih plodova u koji pripadaju višegodišnje vrste koje rastu od prirode na šumskom tlu, od prirodnih sastojina visokog, srednjeg i niskog uzgojnog oblika do raznih degradacijskih oblika šuma eumediterana i submediterana kod kojih se koristi sjeme ili plod za potrebe čovjeka u svježem i prerađenom stanju. Tu pripadaju vrste iz skupine pravog sjemena (Pinus pinea L., Robinia pseudoacacia L.), suhih plodova (Castanea sativa Mill., Corylus avellana L., Quercus robur L.) i mesnatih plodova (Juglans nigra L., Malus sylvestris Mill., Prunus dulcis (Mill.) D., Prunus avium L., Prunus spinosa L., Prunus cerasus L., Prunus padus L., Ribes uva-crispa L.). Važno je naglasiti da su mnoge vrste vrlo ljekovite i njih posebno proučavaju fitofarmaceuti, prehrambeni tehnolozi, etnobotaničari i još mnogi drugi. U Hrvatskoj još nije prikazan točan popis vrsta šumskog drveća, grmlja i prizemnog rašća jestivih i ljekovitih plodova. To je potrebno što hitnije 
napraviti i razlučiti ovu kategoriju od šumskih voćkarica ili šumskog voća. Pretpostavka je kako od prirode u Hrvatskoj raste između 150 i 160 vrsta šumskog drveća, grmlja i prizemnog rašća jestivih i ljekovitih plodova.

Treći pojam odnosi se na samonikle voćke. U tu skupinu pripadaju višegodišnje samonikle vrste koje rastu od prirode, a nastale su sjemenom ili vegetativno, kod kojih se koristi sjeme ili plod za potrebe čovjeka u svježem ili prerađenom stanju, ali ne cvjetovi i ostali vegetativni organi biljke. One rastu od prirode na šumskim i poljoprivrednim tlima. Tu pripadaju vrste iz skupine pravog sjemena (Pinus pinea L.,...), suhih plodova (Castanea sativa Mill., Corylus avellana L.,...) i mesnatih plodova (Cornus mas L., Juglans regia L., Malus sylvestris Mill., Prunus dulcis (Mill.) D., Prunus avium L., Punica granatum L., Rosa canina L., Sambucus nigra L., Taxus baccata L., Viburnum opulus L., Vitis vinifera subsp. sylvestris Hegi,...). Kod vrste Pinus pinea L. postoji velika mogućnost iskorištavanja zbog ekonomske, ekološke, pejzažne, nutritivne i zdravstvene vrijednosti sjemena koje je bogato proteinima, vitaminima A, B, C, D, E, od minerala željezom, magnezijem, fosforom, selenom i cinkom, nezasićenim masnim kiselinama i polifenolima (Jakovljević i sur. 2009).

I ovdje je potrebno što hitnije napraviti i razlučiti ovu kategoriju od šumskih voćkarica ili šumskog voća i šumskog drveća, grmlja i prizemnog rašća jestivih i ljekovitih plodova. Pretpostavka je kako samoniklog voća u Hrvatskoj raste 81 vrsta (najvažnije) iz 44 roda. Kao prvu od važnih mjera, potrebno je napraviti detaljan popis svih vrsta samoniklog voća i njihovu botaničku sistematizaciju.

Četvrti pojam odnosi se na domesticirane voćke. Domestikacija je proces nasljedne reorganizacije divljih životinja i biljaka u domaće i kultivirane oblike koji odgovaraju interesima i potrebama ljudi. Temeljna razlika između domesticiranih životinja i biljaka od njihovih divljih predaka je ta da su stvorena ljudskim radom da zadovolje specifične zahtjeve ili želje, i prilagođavaju se uvjetima u kojima ljudi kontinuirano brinu i njeguju biljke i životinje; brane ih od predatora, hrane ih, pružaju sklonište, štite ih od parazita i tako dalje (Kuhar 2018.). Za domesticirane voćke najbolji su primjeri divlja jabuka (Malus sylvestris Mill., divlja kruška (Pyrus pyraster (L.) Burgsd. i divlja maslina (Olea europaea L.). Od prirodnih vrsta danas na sortnoj listi u svijetu i Republici Hrvatskoj postoji izuzetno mnogo sorata jabuka, krušaka i maslina koje su uzgojene ljudskim radom i raznim tehnikama oplemenjivanja (križanje ili hibridizacija, cijepljenje, itd.). Sortna lista voćaka Republike Hrvatske mijenja se svake godine, a u svijetu je danas nemoguće reći koliko sorata neke voćke postoji. Često su problem i stotine narodnih imena koja se koriste na primjer za samo jednu sortu.

U praksi razlikujemo vrste koje se uzgajaju zbog drvnih šumskih proizvoda i /ili ne drvnih šumskih proizvoda kao što su plodovi, sjeme, listinac i sl.. Šumske voćkarice ili šumsko voće, šumsko drveće, grmlje i prizemno rašće jestivih i ljekovitih proizvoda i domesticirane voćke mogu se uzgajati u prvom redu za pridobivanje drvnih šumskih proizvoda (biomasa) ukoliko imaju vrijedno i skupocjeno drvo, mogu se uzgajati primarno za ne drvne šumske proizvode tj. plodove i sjeme, kao što je primjer sa žižulom, a postoji puno vrsta koje se uzgajaju zbog drvnih i ne drvnih šumskih proizvoda kao što je na primjer drijen, drnjola, drnjule, dren ili drnkalići. Zbog male raspoložive količine drva i njegove izvrsne kvalitete i primjene u drvnoj industriji, drvo drijena postiže izuzetno visoke cijene na licitacijama drva npr. u Republici Sloveniji (https://www.gozd-les.com/ novice/rezultati-12-drazbe-lesa-slovenj-gradcu-2018), a od plodova kao sekundarnih ili ne drvnih šumskih proizvoda može se koristiti svježi plod za potrebe čovjeka ili životinja (najčešće ptica) i za preradu u sirupe, marmelade, likere, rakije i sl. Tako prerađeni plodovi imaju vrlo često visoku cijenu zbog male ponude, a velike potražnje i specifičnosti okusa. Iz tog razloga može se reći da se mnoge vrste koje se uzgajaju primarno zbog ne drvnih šumskih proizvoda zauzimaju posebno mjesto u fitofarmaciji, prehrambenoj tehnologiji, kulinarstvu i voćarstvu. Zbog mogućnosti ekološkog uzgoja, dobre prilagodljivosti vrsta na globalne klimatske promjene, davanja držanih poticaja i ne previše zahtjevne njege, u bliskoj budućnosti bit će sve naglašeniji uzgoj vrsta za pridobivanje ne drvnih šumskih proizvoda u plantažama. Zbog promjene klimatskih uvjeta i sinergizma brojnih nepovoljnih biotskih i abiotskih čimbenika mnoge vrste su danas ugrožene i postepeno se ili naglo suše i propadaju, dok će nekim vrstama šumskih voćkarica kao što je oskoruša pogodovati promjena klime, što će dovesti do širenja njezina areala uz povećanje pogodnosti površina za njezin uzgoj (Drvodelić i sur. 2020).

O značajkama sjemena i rasadničkoj proizvodnji šumskih voćkarica u novije vrijeme pišu Idžojtić i sur. (2006), Oršanić i sur. (2006, 2007, 2009, 2009a), Drvodelić i sur. (2009, 2012, 2015, 2015a, 2019, 2019a, 2020) i Drvodelić (2010, 2016, 2016a, 2017, 2017a).

Buduća istraživanja treba usmjeriti na slabije istražene vrste šumskih voćkarica kroz istraživanja dinamike plodonošenja, najučinkovitijih metoda sabiranja plodova i sjemena, vađenja, čuvanja i predsjetvene pripreme sjemena te rasadničku proizvodnju s ciljem dobivanja kvalitetnih, uniformnih i tržišno profitabilnih šumskih sadnica. Na isti način treba istražiti nutritivne i zdravstvene vrijednosti plodova i sjemena onih vrsta za koje nemamo dovoljno podataka ili su oni starijeg datuma.

Znanstvene i stručne publikacije te popularizacija šumskih voćkarica kroz različite medije povećale su interes za rasadničkom proizvodnjom u rasadnicima Hrvatskih šuma d.o.o.

Cilj rada je dati pregled rasadničke proizvodnje šumskih voćkarica u rasadnicima Hrvatskih šuma d.o.o. za razdoblje od 2012. do 2018. godine. Navedeni pregled je potreban kako bi se utvrdili trendovi u dosadašnjoj rasadničkoj proizvodnji, 
Tablica 1. Rasadnička proizvodnja šumskih sadnica šumskih voćkarica po vrstama u rasadnicima Hrvatskih šuma d.o.0. u 2019./2020. godini prema UŠP, organizacijskim jedinicama i rasadnicima (izvor: Hrvatske šume d.o.o., Služba za proizvodnju i razvoj, travanj 2020.)

Table 1. Production of forest seedlings of forest fruit trees by species in nurseries of Hrvatske šume d.o.o. in 2019/2020 year according to Forest Administration (FD), organizational units and nurseries (source: Hrvatske šume d.o.0., Production and Development Department, April 2020)

\begin{tabular}{|c|c|c|c|c|}
\hline $\begin{array}{l}\text { Redni broj } \\
\text { Ordinal number }\end{array}$ & $\begin{array}{c}\text { UŠP } \\
\text { Forest Administration (FD) }\end{array}$ & $\begin{array}{l}\text { Organizacijska jedinica } \\
\text { Organizational units }\end{array}$ & $\begin{array}{l}\text { Rasadnik } \\
\text { Nursery }\end{array}$ & $\begin{array}{c}\text { Proizvodnja 2019./2020. } \\
\text { Production 2019/2020 }\end{array}$ \\
\hline \multirow{5}{*}{1.} & \multirow{5}{*}{ Koprivnica } & \multirow{5}{*}{$\begin{array}{l}\text { R.J. Rasadničarstvo } \\
\text { Koprivnica }\end{array}$} & Drnje & hrast lužnjak u kontejnerima, topola \\
\hline & & & Močile & bukva, ukrasne sadnice \\
\hline & & & Limbuš & hrast lužnjak, crna joha \\
\hline & & & Zelendvor & $\begin{array}{l}\text { oskoruša, divlja trešnja, pitomi kesten, crni orah,lipa i } \\
\text { repromaterijal za božićna drvca i plantaža božićnih drvaca }\end{array}$ \\
\hline & & & Župetnica & božićna drvca \\
\hline 2. & Ogulin & R.J. Rasadnik Oštarije & Oštarije & smreka, crni bor, obična jela, oskoruša, divlja trešnja \\
\hline 3. & Zagreb & Rasadnik Zagreb & $\begin{array}{l}\text { Lukavec } \\
\text { Brestje }\end{array}$ & $\begin{array}{l}\text { hrast lužnjak, hrast kitnjak, poljski jasen i divlja trešnja } \\
\text { ukrasne sadnice, stablašice i poljski jasen }\end{array}$ \\
\hline
\end{tabular}

zalihe i isporučene količine po vrstama i godinama te kako bi se potaknuo uzgoj onih vrsta koje nedostaju, a važan su čimbenik bioraznolikosti i stabilnosti šumskih ekosustava.

\section{RAZULTATI I RASPRAVA RESULTS AND DISCUSSION}

Proizvodnja i uzgoj sadnica se odvija u 24 rasadnika Hrvatskih šuma d.o.o. na području 14 Uprava šuma Podružnica (UŠP). Unutar devet UŠP osnovane su samostalne Radne jedinice (R.J.). Najviše R.J. imaju UŠP Koprivnica (R.J. Rasadničarstvo Koprivnica) koja ima pet rasadnika, slijedi UŠP Osijek (R.J. Rasadnici Višnjevac) koja ima 4 rasadnika. Ostale UŠP imaju po jedan ili dva rasadnika sa i bez R.J. Ukupna bruto površina svih 24. rasadnika iznosi oko 300 ha. Trgovačko društvo Hrvatske šume d.o.o. u 2019./2020. godini imaju prijavljenu proizvodnju: šumskih sadnica, ukrasnih sadnica, božićnih drvaca, šumskih voćkarica, plemenitih vrsta bjelogorice, repromaterijala za božićna drvca, plantaže božićnih drvaca i stablašice. U tablici 1. prikazana je rasadnička proizvodnja šumskih sadnica šumskih voćkarica po vrstama u rasadnicima Hrvatskih šuma d.o.o. u 2019./2020. godini prema UŠP, organizacijskim jedinicama i rasadnicima. Sve sadnice šumskih voćkarica proizvode se iz sjemena, odnosno generativnim načinom. Kako se radi o vrstama brze ontogeneze u rasadniku, uzgajaju se uglavnom kao sadnice gologa korijena dobi $1+0$.

Rasadnička proizvodnja šumskih voćkarica i drveća jestivih i ljekovitih plodova je prisutna u samo tri rasadnika i to u rasadniku Zelendvor (R.J. Rasadničarstvo Koprivnica, UŠP Koprivnica), rasadniku Oštarije (R.J. Rasadnik Oštarije, UŠP Ogulin) i u rasadniku Lukavec, organizacijska jedinica Rasadnik Zagreb, UŠP Zagreb. U navedena tri rasadnika ukupno se proizvodi (2019./2020.) svega četiri vrste šumskih sadnica šumskih voćkarica i drveća jestivih i ljekovitih plodova: oskoruša, divlja trešnja, pitomi kesten $\mathrm{i}$ crni orah. Sve četiri vrste se proizvode u rasadniku Zelen- dvor, u rasadniku Oštarije proizvode se šumske sadnice oskoruše i divlje trešnje, a u rasadniku Lukavec samo šumske sadnice divlje trešnje.

Proizvodnja i isporuka sadnog materijala šumskih voćkarica iz rasadnika Hrvatskih šuma d.o.o. za razdoblje od 2012. do 2017. godine - Production and delivery of planting material of forest fruits trees from the nursery of Hrvatske šume d.o.o. for the period 2012 to 2017

\section{Pitomi kesten (Castanea sativa Mill.) \\ 1. Sweet chestnut (Castanea sativa Mill.)}

Iz slike 1. je vidljivo kako je u šest istraživanih godina proizvodnje najviše sadnica pitomog kestena na zalihama (30.09.) bilo u 2015. godini u iznosu od 16200 komada,

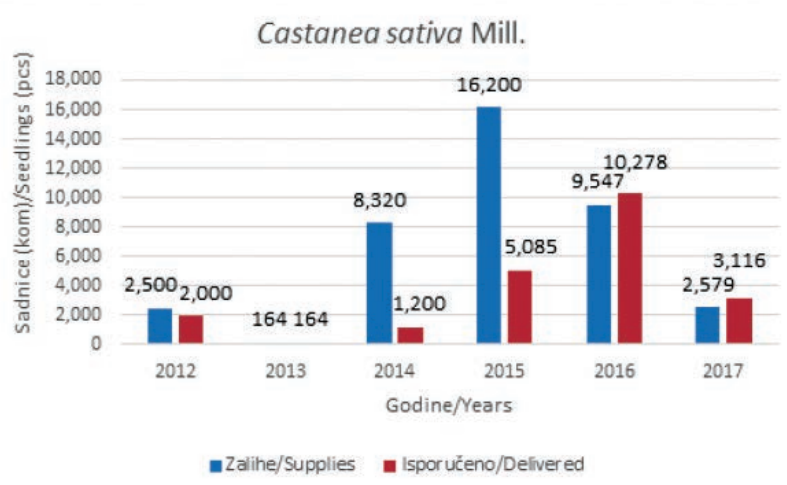

Slika 1. Proizvodnja i isporuka sadnica pitomog kestena iz rasadnika Hrvatskih šuma d.o.0. za razdoblje od 2012. do 2017. godine. Zalihe sadnica (plavi stupci) iskazuju se s obveznom inventurom (30.09.) u rasadnicima. Crveni stupci označuju isporuku sadnica iz rasadnika u tekućoj godini.

Figure 1. Production and delivery of sweet chestnut seedlings from the nursery of Hrvatske šume d.o.0. for the period 2012 to 2017. Stocks of seedlings (blue columns) are reported with mandatory inventory (30.09.) in nurseries. Red columns indicate the delivery of seedlings from the nursery in the current year. 
slijedi 2016. godina s 9547 komada, 2014. godina s 8320 komada, 2017. godina s 2579 komada, 2012. godina s 2500 komada i 2013. godina sa 164 komada.

U promatranom istraživanom razdoblju (2012.-2017.) u svim rasadnicima Hrvatskih šuma d.o.o. ukupno je bilo na zalihama 39310 komada šumskih sadnica pitomoga kestena, a isporučeno je iz rasadnika 21843 komada. Iz izračuna se može vidjeti razlika između proizvodnje i isporuke sadnica u iznosu od 17467 komada.

\section{Crni orah (Juglans nigra L.)}

\section{Black walnut (Juglans nigra L.)}

Iz slike 2. vidljivo je kako je u šest istraživanih godina proizvodnje najviše sadnica pitomog crnog oraha na zalihama (30.09.) bilo u 2017. godini u iznosu od 43000 komada, slijedi 2013. godina sa 42000 komada, 2012. godina sa 40 470 komada, 2014. godina sa 40000 komada, 2015. godina s 15000 komada i 2016. godina s 3200 komada.

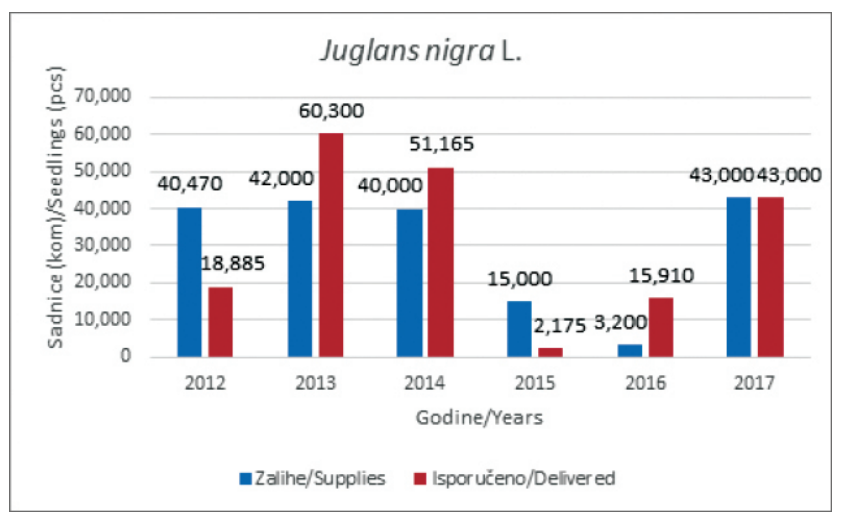

Slika 2. Proizvodnja i isporuka sadnica crnog oraha iz rasadnika Hrvatskih šuma d.o.o. za razdoblje od 2012. do 2017. godine.

Figure 2. Production and delivery of black walnut seedlings from the nursery of Hrvatske šume d.o.o. for the period 2012. to 2017.

U promatranom istraživanom razdoblju (2012.-2017.) u svim rasadnicima Hrvatskih šuma d.o.o. ukupno je bilo na zalihama 183670 komada šumskih sadnica crnog oraha, a isporučeno je iz rasadnika 191435 komada.

Iz izračuna se može vidjeti kako je 7765 komada sadnica više isporučeno nego što je proizvedeno, što nije logično.

\section{Divlja trešnja (Prunus avium L.)}

3. Wild cherry (Prunus avium L.)

Iz slike 3. vidljivo je kako je u šest istraživanih godina proizvodnje najviše sadnica divlje trešnje na zalihama (30.09.) bilo u 2016. godini u iznosu od 42000 komada, slijedi 2017. godina sa 25053 komada, 2014. godina sa 22340 komada, 2015. godina s 11676 komada, 2012. godina s 9004 komada i 2013. godina s 3914 komada.

U promatranom istraživanom razdoblju (2012.-2017.) u svim rasadnicima Hrvatskih šuma d.o.o. ukupno je bilo na

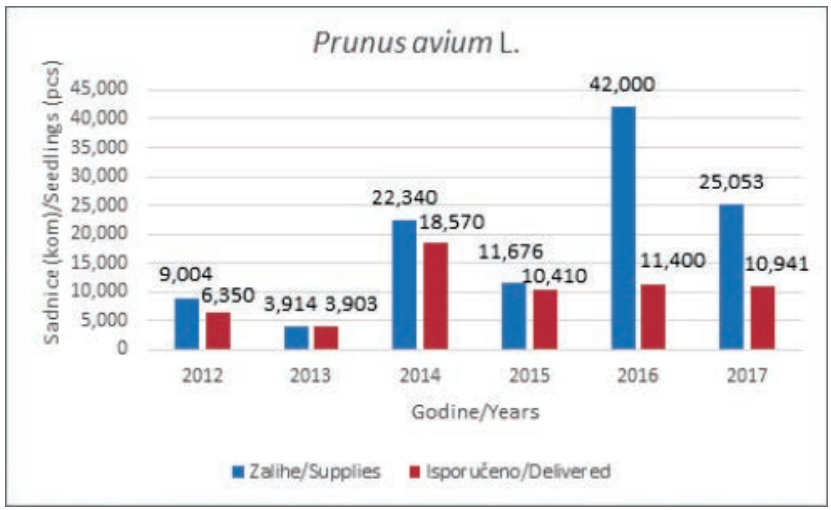

Slika 3. Proizvodnja i isporuka sadnica divlje trešnje iz rasadnika Hrvatskih šuma d.o.o. za razdoblje od 2012. do 2017. godine.

Figure 3. Production and delivery of wild cherry seedlings from the nursery of Hrvatske šume d.o.o. for the period 2012 to 2017.

zalihama 113987 komada šumskih sadnica divlje trešnje, a isporučeno je iz rasadnika 61574 komada.

Iz izračuna se može vidjeti kako je 52413 komada sadnica više uzgojeno nego što je isporučeno.

4. Divlja kruška (Pyrus pyraster (L.) Burgsd.)

4. Wild pear (Pyrus pyraster (L.) Burgsd.)

Iz slike 4. vidljivo je kako je u šest istraživanih godina proizvodnje najviše sadnica divlje kruške na zalihama (30.09.) bilo u 2016. godini u iznosu od 2000 komada, slijedi 2017. godina s 1642 komada, 2014. godina sa 720 komada i 2015. godina s 520 komada. U 2012. i 2013. godini nije bilo na zalihama sadnica divlje kruške.

U promatranom istraživanom razdoblju (2012.-2017.) u svim rasadnicima Hrvatskih šuma d.o.o. ukupno je bilo na zalihama 4882 komada šumskih sadnica divlje kruške, a isporučeno je iz rasadnika 2860 komada.

Iz izračuna se može vidjeti kako je 2022 komada sadnica više uzgojeno nego što je isporučeno.

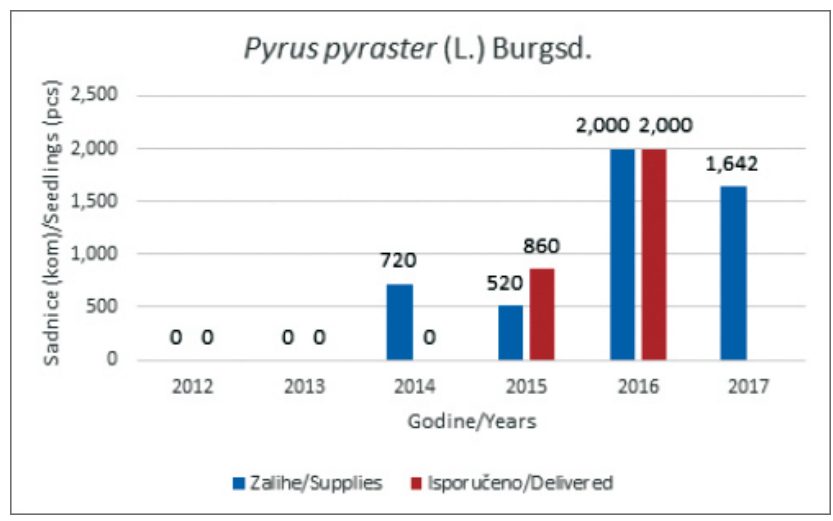

Slika 4. Proizvodnja i isporuka sadnica divlje kruške iz rasadnika Hrvatskih šuma d.0.0. za razdoblje od 2012. do 2017. godine.

Figure 4. Production and delivery of wild pear seedlings from the nurseries of Hrvatske šume d.o.o. for the period 2012 to 2017. 


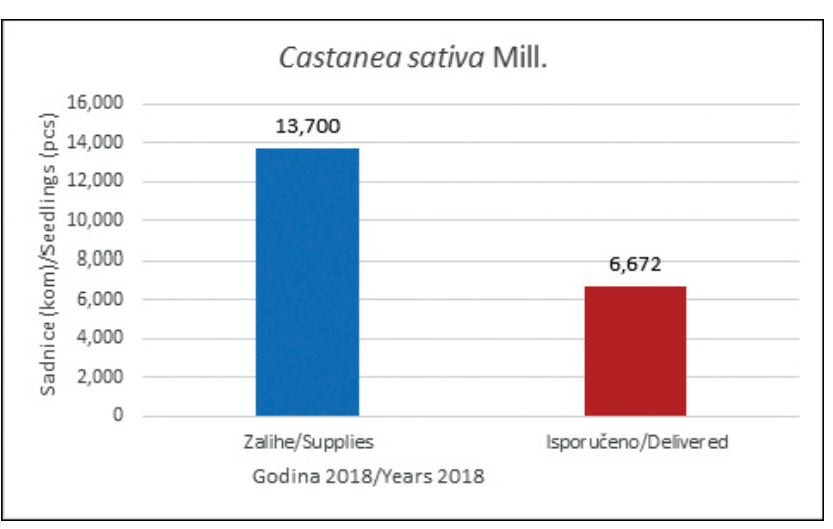

Slika 5. Proizvodnja i isporuka sadnica pitomog kestena iz rasadnika Hrvatskih šuma d.o.0. u 2018. godini

Figure 5. Production and delivery of sweet chestnut seedlings from nurseries of Croatian forests d.0.0. in 2018

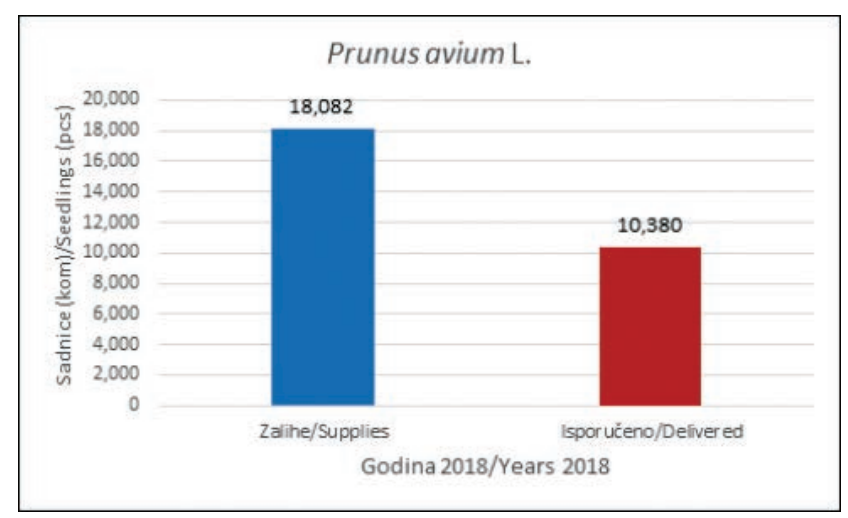

Slika 6. Proizvodnja i isporuka sadnica divlje trešnje iz rasadnika Hrvatskih šuma d.0.0. u 2018. godini

Figure 6 . Production and delivery of wild cherry seedlings from nurseries of Croatian forests d.0.0. in 2018

Na slikama 5. i 6. prikazana je proizvodnja i isporuka sadnica pitomog kestena i divlje trešnje iz rasadnika Hrvatskih šuma d.o.o. u 2018. godini

\section{Pitomi kesten (Castanea sativa Mill.)}

5. Sweet chestnut (Castanea sativa Mill.)

Iz slike 5. vidljivo je kako je u 2018. godini u svim rasadnicima Hrvatskih šuma d.o.o. na zalihama bilo 13700 komada sadnica, dok je isporučeno 6 672, što znači kako je ostalo u rasadnicima 7028 komada sadnica.

\section{Divlja trešnja (Prunus avium L.)}

6. Wild cherry (Prunus avium L.)

Iz slike 6. vidljivo je kako je u 2018. godini u svim rasadnicima Hrvatskih šuma d.o.o. na zalihama bilo 18082 komada sadnica, dok je isporučeno 10380 , što znači kako je ostalo u rasadnicima 7702 komada sadnica.

Zalihe i isporučene sadnice šumskih voćkarica po vrstama drveća iz rasadnika Hrvatskih šuma d.o.o. za razdoblje od 2012. do 2018. godine

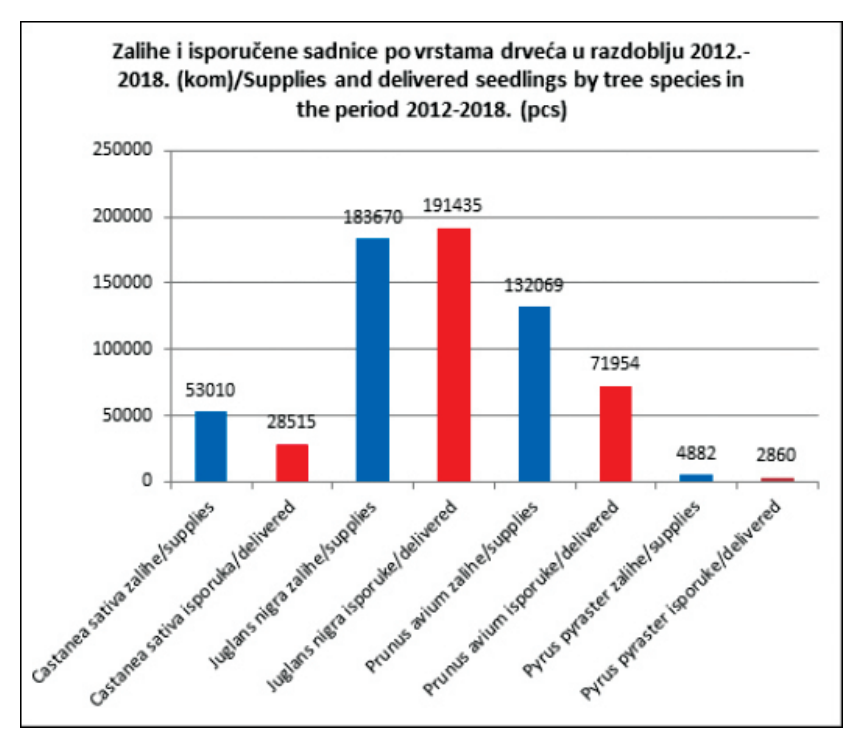

Slika 7. Zalihe i isporučene sadnice šumskih voćkarica po vrstama drveća iz rasadnika Hrvatskih šuma d.o.o. za razdoblje od 2012. do 2018. godine

Figure 7. Supplies and delivered seedlings of forest fruit trees by tree species from the nursery of Hrvatske šume d.o.o. for the period from 2012 to 2018

Iz slike 7. vidljivo je kako je na zalihama ili u proizvodnji, u svim rasadnicima Hrvatskih šuma d.o.o. za razdoblje od 2012. do 2018. godine najviše bilo sadnica crnog oraha $u$ iznosu od 183670 komada, slijede sadnice divlje trešnje sa 132069 komada, pitomog kestena s 53010 komada i divlje kruške sa 4882 komada.

Najviše isporučenih sadnica, sukladno proizvodnji, bilo je kod crnog oraha i to u iznosu od 191435 komada, slijede sadnice divlje trešnje sa 71954 komada, pitomog kestena s 28515 komada i divlje kruške s 2860 komada.

Iz izračuna se može vidjeti kako je 78867 komada sadnica više uzgojeno nego što je isporučeno.

U 2018. godini posijano je $1104 \mathrm{~kg}$ sjemena pitomog kestena, $1500 \mathrm{~kg}$ sjemena crnog oraha i $13 \mathrm{~kg}$ sjemena divlje trešnje. Ostale šumske voćkarice nisu sijane. U 2019. godini u Dunemannove lijehe posijano je sjeme oskoruše koje je preležalo i rezultati klijavosti sjemena u proljeće 2020. godine su iznenađujuće dobri. Ostale vrste šumskih voćkarica, šumskog drveća, grmlja i prizemnog rašća jestivih i ljekovitih plodova, samoniklih voćki i domesticirani voćki nisu sijane.

U promatranom istraživanom razdoblju (2012.-2018.) u svim rasadnicima Hrvatskih šuma d.o.o. proizvodilo se samo 4 vrste šumskih voćkarica s ukupnom zalihom ili proizvodnjom od 373631 komada šumskih sadnica i isporukom od 294764 komada, što je jako mali broj u odnosu na proizvodnju sadnica glavnih vrsta drveća. Perić i dr. (2009) pišu kako se u svih 49 rasadnika upisanih u Upisnik proizvođača šumskih sadnica u Republici Hrvatskoj proizvo- 
dilo oko 20 vrsta četinjača (sjeme se skuplja na 1350 ha priznatih ili izabranih sjemenskih sastojina) te oko $20 \mathrm{vr}$ sta listopadnog drveća (sjeme se skuplja na 16309 ha priznatih ili izabranih sastojina). Količina i kvaliteta proizvedenoga šumskog reprodukcijskog materijala varirala je od godine do godine. Najzastupljenije su bile sljedeće vrste bjelogorice: hrast lužnjak, hrast kitnjak i poljski jasen. Od četinjača najzastupljenija je bila obična smreka. U istraživanih 17 godina (od 1992. do 2008. godine) ukupno je proizvedeno 484,85 milijuna sadnica, $s$ najmanjom proizvodnjom od 12,03 milijuna sadnica u 2005. godini te najvećom proizvodnjom od 46,85 milijuna u 1998. godini.

U rasadnicima Hrvatske šume d.o.o. trebale bi se sijati sve vrste šumskih voćkarica, jer postoji mogućnost sabiranja autohtonog sjemena i poznata rasadnička proizvodnja. Sadnice šumskih voćkarica treba unositi prilikom umjetne obnove šuma kako bi se povećala biološka raznolikost, stabilnost, produktivnost i vitalitet šumskih ekosustava, što u konačnici znači i veće gospodarske i opće korisne vrijednosti šuma koje doprinose boljoj kvaliteta života ljudi.

\section{ZAKLJUČCI CONCLUSIONS}

Najjednostavnija definicija voća glasila bi kako su to višegodišnje biljke čije plodove možemo jesti svježe. U navedenoj definiciji mnogi traže izuzetke i sigurno je kako nije do kraja razjašnjena. Tako je i s podjelom voćaka koja je još do danas predmet rasprava kako unutar znanosti tako i u praksi. Šumske voćkarice ili šumsko voće do sada nitko nije podijelio u skupine prema osnovnim obilježjima i građi plodova iz razloga što se neke vrste mogu svrstati u pojedinu skupinu ali ne sve.

U šumarstvu treba razlikovati sljedeće pojmove: šumske voćkarice ili šumsko voće, šumsko drveće, grmlje i prizemno rašće jestivih i ljekovitih plodova, samonikle voćke i domesticirane voćke.

Trgovačko društvo Hrvatske šume d.o.o. u 2019./2020. godini imaju prijavljenu proizvodnju: šumskih sadnica, ukrasnih sadnica, božićnih drvaca, šumskih voćkarica, plemenitih vrsta bjelogorice, repromaterijala za božićna drvca, plantaže božićnih drvaca i stablašice. Što se tiče proizvodnje šumskih voćkarica i drveća jestivih i ljekovitih plodova ona je prisutna u samo tri rasadnika: Zelendvor, Oštarije i Lukavec. Proizvodnju je potrebno planirati s obzirom na realne potrebe za sadnjom na terenu, uzimajući u obzir brzi rast šumskih voćkarica u mladosti i mogućnosti da sadnice prerastu u rasadniku ukoliko se ne isporuče na vrijeme. Rasadničku proizvodnju potrebno je povećati u količinama s postojećim vrstama, ali i proizvodnjom mnogih drugih vrsta koje se do sada nisu uzgajale s obzirom na postojeće i nove konvencije o biološkoj raznolikosti šuma, europskim i nacionalnim strategijama i zakonodavstvu.

U navedena tri rasadnika ukupno se proizvodi (2019./2020.) svega četiri vrste šumskih sadnica šumskih voćkarica i drveća jestivih i ljekovitih plodova: oskoruša, divlja trešnja, pitomi kesten i crni orah. Sve četiri vrste se proizvode u rasadniku Zelendvor, u rasadniku Oštarije proizvode se šumske sadnice oskoruše i divlje trešnje, a u rasadniku Lukavec samo šumske sadnice divlje trešnje.

Na zalihama ili u proizvodnji, u svim rasadnicima Hrvatskih šuma d.o.o. za razdoblje od 2012. do 2018. godine najviše je bilo sadnica crnog oraha u iznosu od 183670 komada, slijede sadnice divlje trešnje s 132069 komada, pitomog kestena s 53010 komada i divlje kruške s 4882 komada. Najviše isporučenih sadnica, sukladno proizvodnji, bilo je kod crnog oraha i to u iznosu od 191435 komada, slijede sadnice divlje trešnje s 71954 komada, pitomog kestena s 28515 komada i divlje kruške s 2860 komada. U promatranom istraživanom razdoblju (2012.-2018.) u svim rasadnicima Hrvatskih šuma d.o.o. proizvodilo se samo 4 vrste šumskih voćkarica s ukupnom zalihom ili proizvodnjom od 373631 komada šumskih sadnica i isporukom od 294764 komada.

Pitomi kesten pripada u skupinu neklimakterijskog šumskog drveća jestivih i ljekovitih plodova (suhi plodovi), samoniklog i domesticiranog voća. Danas se primarno uzgaja zbog vrijedne biomase, jer ima skupocjeno i vrlo trajno drvo (kolje za vinograde i ograde) a sekundarno zbog plodova u prerađenom stanju ili za proizvodnju generativnih podloga za cijepljenje ukrasnih kultivara za potrebe urbanog šumarstva ili u voćarstvu za cijepljenje brojnih kultiviranih sorti.

Crni orah pripada u skupinu neklimakterijskog šumskog drveća jestivih i vrlo ljekovitih plodova (suhi plodovi). Danas se primarno uzgaja zbog vrijedne drvne biomase (drvni šumski proizvod), jer ima skupocjeno i vrlo trajno drvo (kolje za vinograde i ograde), a sekundarno zbog ljekovitih plodova (ne drvni šumski proizvod). Nalazi se u skupini šumskog drveća jestivih i ljekovitih plodova s najvećom cijenom $\mathrm{m}^{3}$ drva trenutno na tržištu Hrvatske i mnogih drugih zemalja članica EU.

Divlja trešnja pripada u skupinu neklimakterijske šumske voćkarice ili šumskoga voća, drveća jestivih i ljekovitih plodova (mesnati plodovi), samonikle voćne vrste ili voćke i domesticirane voćke. Danas se primarno uzgaja zbog biomase jer ima drvo vrlo lijepe boje i široke primjene u drvnoj industriji i proizvodnji namještaja i proizvoda od drva, a samo sekundarno zbog plodova koji se konzumiraju u svježem i češće u prerađenom stanju ili za proizvodnju generativnih podloga za cijepljenje ukrasnih kultivara japan- 
skih trešanja za potrebe urbanog šumarstva ili u voćarstvu za cijepljenje brojnih kultiviranih sorti.

Divlja kruška pripada u skupinu klimakterijske šumske voćkarice s mesnatim usplođem, u skupinu šumskog drveća jestivih i ljekovitih plodova, u samonikle voćke i domesticiranu voćku. Uzgaja se primarno zbog vrijedne biomase jer ima skupocjeno drvo, a sekundarno zbog plodova. Divlja kruška pripada u skupinu šumskih voćkarica ili šumskoga voća, drveća jestivih i ljekovitih plodova (mesnati plodovi), samonikle voćne vrste ili voćke i domesticirane voćke. Danas se primarno uzgaja zbog biomase jer ima trajno, lijepo i skupocjeno drvo sa širokom primjenom u drvnoj industriji i proizvodnji namještaja i proizvoda od drva, a samo sekundarno zbog plodova koji se konzumiraju u svježem i češće u prerađenom stanju ili za proizvodnju generativnih podloga za cijepljenje brojnih kultiviranih sorti u voćarstvu.

\section{LITERATURA}

\section{LITERATURE}

- Andrašić, D. D., 1980: Šumarska enciklopedija II izdanje, Jugoslavenski leksikografski zavod, str. 36, Zagreb.

- Drvodelić, D., M. Oršanić, T. Jemrić, 2009: Morfološka svojstva plodova i sjemena oskoruše (Sorbus domestica L.). Radovi, 44(1): 5-15.

- Drvodelić, D., 2010:Značajke sjemena i rasadnička proizvodnja nekih vrsta roda Sorbus L... Doktorski rad, Sveučilište u Zagrebu, Šumarski fakultet, 568 str.

- Drvodelić, D., M. Oršanić, Z. Zeman, 2012: Uspjeh pošumljavanja jednogodišnjim $(1+0)$ i školovanim $(1+1)$ sadnicama divlje kruške (Pyrus pyraster Burgsd.). Šumarski List, 7-8: 355-366.

- Drvodelić, D., T. Jemrić, M. Oršanić, V. Paulić, 2015: Krupnoća ploda divlje jabuke (Malus sylvestris (L.) Mill.): utjecaj na morfološko-fiziološka svojstva sjemena. Šumarski list, 3-4: 145153.

- Drvodelić, D., T. Jemrić, M. Oršanić, 2015a: Oskoruša: važnost, uporaba i uzgoj . Sveučilište u Zagrebu-Šumarski fakultet, sveučilišna monografija, 182 str.

- Drvodelić, D., 2016: Razmnožavanje duda. Gospodarski list.

- Drvodelić, D., 2016a: Cijepljenje pitomog kestena. Gospodarski list.

- Drvodelić, D., 2017: Jarebika-zaboravljena, a korisna. Gospodarski kalendar. Gospodarski list, Zagreb.

- Drvodelić, D., 2017a: Plantažni uzgoj kestena. Gospodarski kalendar. Gospodarski list, Zagreb.

- Drvodelić, D., T. Jemrić, M. Oršanić, 2019: Jarebika: važnost, uzgoj i uporaba. Sveučilište u Zagrebu-Šumarski fakultet, sveučilišna monografija,166 str.
- Drvodelić, D., I. Poljak, I. Perković, M. Šango, K. Tumpa, I. Zegnal, M. Idžojtić, 2019a: Ispitivanje laboratorijske klijavosti pitomoga kestena (Castanea sativa Mill.) u skladu s pravilima ISTA. Šumarski list, 9-10: 469-477.

- Drvodelić, D., M. Oršanić, I. Poljak, V. Paulić, V. Pintar, 2020: Sezonska varijabilnost plodova i utjecaj klimatskih promjena na prirodnu rasprostranjenost oskoruše (Sorbus domestica L.) u Hrvatskoj, Zbornik radova „Gospodarenje šumama u uvjetima klimatskih promjena i prirodnih katastrofa", ur. Igor Anić, Hrvatska akademija znanosti i umjetnosti, Zagreb, 37-48 str.

- Idžojtić, M., M. Zebec, D. Drvodelić, 2006: Varijabilnost populacija brekinje u kontinentalnom dijelu Hrvatske prema morfološkim obilježjima lišća i plodova. Glasnik za šumske pokuse. Posebno izdanje, 5: 305-314.

- Jakovljević, T., M. Gradečki-Poštenjak, I. Radojčić Redovniković, I., 2009: Sjeme pinije (Pinus pinea L.), šumski reprodukcijski materijal i hrana. Radovi, 44(1): 29-35.

- Kapper, O. G., 1952: Rjabina obyknovennaja, iligorjkaja. Lesn. Hoz., 5(8): 37-38.

- Kuhar, B., 2018: Domestikacijski centri i domestikacija životinja. Sveučilište u Zagrebu, Agronomski fakultet, završni rad, 22 str.

- Matić, S., J. Vukelić, 2001: Speierling und Elsbeere in den Wäldern Kroatiens. Corminaria 16: 31-33.

- Oršanić, M., D. Drvodelić, I. Anić, S. Mikac, 2006: Morphological-biological properties of fruit and seed of the genus Sorbus (L.) species. Periodicum biologorum, 108(6): 693-706.

- Oršanić, M., D. Drvodelić, I. Kovačević, 2007: Rasadnička proizvodnja sadnica crnoga oraha (Juglans nigra L.). Šumarski list, 5-6: 207-217.

- Oršanić, M., D. Drvodelić, T. Jemrić, I. Anić, S. Mikac, 2009: Variability of morphological and biological characteristics of Wild Service Tree (Sorbus torminalis (L.) Crantz) fruits and seeds from different altitudes. Periodicum biologorum, 111(4): 495-504.

- Oršanić, M., D. Drvodelić, T. Jemrić, 2009a: Morfološka svojstva plodova i sjemena oskoruše (Sorbus domestica L.). Knjiga sažetaka „Uloga i značaj šumskog sjemena u obnovi šuma“, 50. obljetnica šumskog sjemenarstva u Republici Hrvatskoj. Zagreb, 28-29. listopada 2009.

- Perić, S., M. Tijardović, M. Oršanić, J. Margaletić, 2009: Rasadnička proizvodnja i važnost šumskoga reprodukcijskog materijala u RH. Radovi, 44(1): 17-26.

- Regent, B., 1980: Šumsko sjemenarstvo. Jugoslovenski poljoprivredno- šumarski centar, Beograd, 201 str.

- Šatalić, S., Š. Štambuk, 1997: Šumsko drveće i grmlje jestivih plodova. Državna uprava za zaštitu okoliša, Zagreb, 143 str.

- https://www.enciklopedija.hr/Natuknica.aspx?ID=65101 (17.06.2020.)

- https://www.gozd-les.com/novice/rezultati-12-drazbe-lesaslovenj-gradcu-2018 (17.06.2020.)

- http://pinova.hr/hr_HR/baza-znanja/vocarstvo/vocne-vrste (17.06.2020.) 


\section{SUMMARY}

The article defines the term forest fruit trees or forest fruits that have been present in Croatian forestry for years and compares the term with other terms that are not synonymous and refer to forest trees, shrubs and ground growth of edible and medicinal fruits, wild fruits and domesticated fruits. Typical species representatives are listed for each term. The production by types of trees in the nurseries of Hrvatske šume d.o.o. is shown. in 2019/2020 years according to Forest Administration (FD), organizational units and nurseries. Regarding the production of forest fruit trees, edible and medicinal fruit trees, wild fruits and domesticated fruits, it is present in only three nurseries of Hrvatske šume d.o.o. (Zelendvor, Oštarije and Lukavec). In these three nurseries, a total of only four species from the above four categories are produced (2019/2020): service tree, wild cherry, sweet chestnut and black walnut. All four species are produced in the Zelendvor nursery, while in the Oštarije nursery, wild cherry seedlings are also produced, and in the Lukavec nursery only wild cherry seedlings are produced. The production and delivery of planting material of these species from the nursery of Hrvatske šume d.o.o. is shown. for the period 2012 to 2017. In stock or in production, in all nurseries of Hrvatske šume d.o.o. for the period from 2012 to 2018, there were mostly black walnut seedlings in the amount of 183,670 pieces, followed by seedlings of wild cherry with 132,069 pieces, sweet chestnut with 53,010 pieces and wild pear with 4,882 pieces. The most delivered seedlings, according to production, were black walnuts in the amount of 191,435 pieces, followed by wild cherry seedlings with 71,954 pieces, sweet chestnuts with 28,515 pieces and wild pears with 2,860 pieces. In the observed research period (20122018) in all nurseries of Hrvatske šume d.o.o. only 4 species from the above categories were produced with a total stock or production of 373,631 pieces of forest seedlings and a delivery of 294,764 pieces. In total, for all four species, it can be seen that 78,867 pieces of seedlings were grown more than delivered. Due to the possibility of organic farming, good adaptability of species to global climate change, providing incentives and not too demanding care, in the near future there will be increasing emphasis on species breeding to obtain secondary or non-timber forest products in plantations. Due to changing climatic conditions and the synergy of a number of unfavorable biotic and abiotic factors, many indigenous species are endangered today and are gradually or abruptly drying up and decaying. Some species of forest fruit trees, forest trees, shrubs and ground growth of edible and medicinal fruits, wild fruits and domesticated fruits will benefit from climate change, which will lead to the expansion of their natural range with increasing potential areas suitable for artificial cultivation.

KEY WORDS: nursery production, black walnut, wild cherry, wild pear, service tree 